海中に係留された球形浮体の運動と係留力

Mot $i$ on and Mooring Force of a Submerged Sphere due to Waves

$\begin{array}{cllll}\text { 建設省土木研究所 } & \text { 正 } & \text { 員 } & \text { 山口 } & \text { 修 } \\ \text { 同 } & \text { 正 } & \text { 員 } & \text { 橋本 } & \text { 厷 }\end{array}$

1. 緒言

海中に 1 点緊張係留された球形浮体の規則波による運動や係留力についてはこれまでにも多くの研究が行な われてきたが ${ }^{1)}$ ，不規則波中に打ける解析は汪とんど行なわれていない。本研究では水面に浮んだ浮体の運動 の計算に対して船舶流体力学で一般に用いられる近似解法 ${ }^{2)}$ を用いて海中に倸留された球形浮体の規則波及び 不規則波中の運動特性と係留力を推定する。この方法では付加質量や減衰定数を実験的に求心て運動方程式 に代入するといら煩雑さはあるが，複雑な計算を行らことなく，運動の大略の推定が可能である。ここでは 粘性力の効果を取入れた解析方法によって, 規則波及び不規則波中の運動と係留力を計算し, 模型実験及び現 地実験によってその妥当性を検証したいと考える。

2. 規則波中の応答解析

$2-1$ 運動方程式の構成

目ー1 亿示すように座標軸を定め, 球形浮体に作用する外力の計算 が容易なように球座標系を併用する。波は $(-\mathrm{x})$ 方向に進行する規則波 を考える。なお,ここで取扱ら浮体の運動は二次元定常運動とし, 運 動は微小とする。さらに鉛直方向の波強制力が余裕浮力に比べて小さ いとすれば, 海中に係留された球形浮体重心の接線方向の運動方程式 は, 粘性力の効果を非線型抗力として水粒子と浮体運動の相対速度の 2 乗に比例する形で導入すると支点 0 を回転の中心として次のように 構成される。

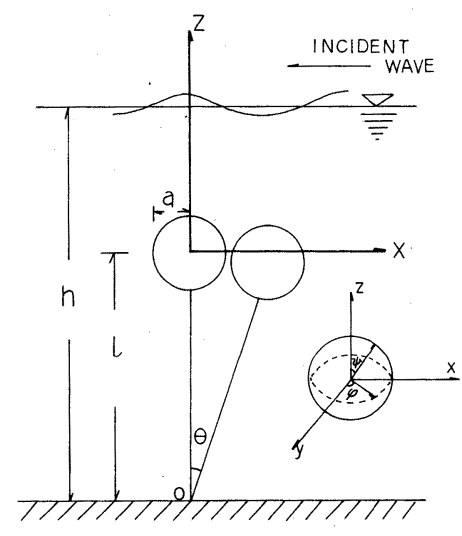

図一 1 座標系

$$
\mathrm{I} \ddot{\theta}+\left(\mathrm{I}^{\prime} \ddot{\theta}+\mathrm{C}_{1} \ell^{2} \dot{\theta}\right)+\mathrm{C}_{3} \ell \theta=\mathbf{F x} \ell+\mathrm{C}_{2} \ell(\mathrm{u}-\dot{\theta} \ell)|\mathrm{u}-\dot{\theta} \ell|
$$

ここで, $\quad \mathrm{C}_{2}=\mathrm{C}_{\mathrm{D}} \mathrm{K}_{\mathrm{C}}, \quad \mathrm{C}_{3}=\left(\frac{4}{3} \rho \pi \mathrm{a}^{3}-\mathrm{m}\right) \mathrm{g}$ である。

(1)式に打いて左辺第 1 項は慣性力によるモーメント，第 2 項は静水中で運動する物体に作用する力によるモ ーメント, 第 3 項は静的復元力によるモーメントに対応し，右辺第 1 項は固定された物体に作用する力による モーメント，第 2 項は粘性力によるモーメントに対応する。また I， I'はそれぞれ慣性モーメント，付加慣性 モーメント, $\mathrm{C}_{1}$ は線型減衰係数, $\mathrm{m}$ は浮体の質量, $\mathrm{C}_{\mathrm{D}}$ は抗力係数, $\mathrm{g}$ は重力の加速度, $\mathrm{U} 0$ 点から浮体重 心をでの距離, $\mathrm{a}$ は浮体の半径, $\mathrm{F} \mathrm{x}$ は水平方向の波強制力, $\mathrm{Kc}=\frac{1}{2} \rho \pi \mathrm{a}^{2}, \rho$ は海水の密度である。

法線方向の運動方程式は次式で与えられる。

$$
\mathrm{m} \frac{\mathrm{v}^{2}}{\ell}=\mathrm{T}-\mathrm{Fz}-\mathrm{C}_{3}
$$

ここで, $\mathrm{V}$ は 0 点を中心とする球形浮体重心の回転運動の接線速度で, $\mathrm{V}=e \dot{\theta}, \mathrm{T}$ は係留索に作用する力, $\mathrm{F} z$ は浮体に作用する鉛直方向の波強制力である。(1), (2)式を解くには運動方程式の係数及び波強制力の值を 与える必要があるが, 付加慣性モーメント, 減衰定数の值は静水中での自由動摇試験によって得られたものを 使用する。鉛直及び氷平方向の波強制力は浮体の全表面に作用する圧力を積分することによって求まる力

(Froude - Kriloff's force) と進行してきた波が浮体のため奴く乱される結果浮体に作用する力 (Diffraction wave force)の和として近似する。Diffraction wave forceはさらに水粒子の加 
速度と速度に比例する項に分割できるが, 浮体の径が波長に比べて小さければ皮粒子の速度に比例した力は無 視できるためここでは水粒子加速度に比例する力のみで表現することとすれば，以下のよらにして計算される。 $2-2$ 波強制力の計算

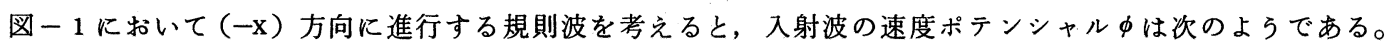

$$
\phi=-\zeta_{0} \frac{\mathrm{g}}{\sigma} \frac{\cosh \mathrm{k}(\ell+r \cos \psi)}{\cosh \mathrm{kh}} \sin (\mathrm{k} r \sin \psi \sin \varphi+\sigma \mathrm{t})
$$

水平及び鉛直方向の水粒子速度及び加速度, $(\mathrm{u}, \dot{\mathrm{u}}),(\mathrm{w}, \dot{\mathrm{w}})$, それに变動圧力, $\mathrm{p}$ はそれぞれ次式で与え られる。

$$
\mathrm{u}=\frac{\partial \phi}{\partial x}, \quad \dot{\mathrm{u}}=\frac{\partial \mathrm{u}}{\partial \mathrm{t}}, \quad \mathrm{w}=\frac{\partial \phi}{\partial \mathrm{z}}, \quad \dot{\mathrm{w}}=\frac{\partial \mathrm{w}}{\partial \mathrm{t}}, \quad \mathrm{p}=-\rho \frac{\partial \phi}{\partial \mathrm{t}}
$$

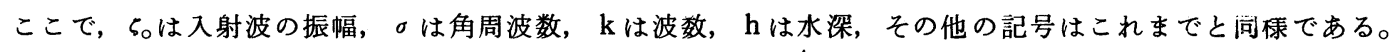
(4)式の変動圧力から鉛直及び水平方向のFroude-Kriloff's force, Fz ( F.K ), F x (F.K) はそれぞ れ次式で計算される。

$$
\begin{aligned}
& \mathrm{Fz}(\mathrm{F} \cdot \mathrm{K})=-\int_{0}^{\varphi=2 \pi} \int_{0}^{\varphi=\pi}\{\mathrm{p}\} \mathrm{r}=\mathrm{a} \mathrm{a}^{2} \cos \psi \sin \psi \mathrm{d} \psi \mathrm{d} \varphi \cos \sigma \mathrm{t} \\
& \mathrm{Fx}(\mathrm{F} \cdot \mathrm{K})=-\int_{0}^{\varphi=2 \pi} \int_{0}^{\phi=\pi}\{\mathrm{p}\} \mathrm{r}=\mathrm{a}^{\mathrm{a}^{2}} \sin ^{2} \psi \sin \varphi \mathrm{d} \psi \mathrm{d} \varphi \sin \sigma \mathrm{t}
\end{aligned}
$$

(5)，(6)式は直接には積分できないため; 実際の計算ではベッセル関数の展開公式を利用して $\varphi$ に関する積分を 行った後に, $(0 \sim \pi)$ の間を 1000 等分して, シンプッンの公式により数値積分を行った。鉛直及 び水平方向のDiffraction wave force,Fz(D.F)，Fx(D.F)はそれぞれ次式のよらになる。

$$
\begin{aligned}
& \mathrm{Fz}(\mathrm{D} \cdot \mathrm{F})=-\mathrm{mz} \zeta_{0} \sigma^{2} \lambda_{0} \cos \sigma \mathrm{t} \\
& \mathrm{Fx}(\mathrm{D} \cdot \mathrm{F})=\mathrm{mx} \zeta_{0} \sigma^{2} \text { qo } \sin \sigma \mathrm{t}
\end{aligned}
$$

ここで, $\lambda 0=\mathrm{sinh} \mathrm{k} \ell / \mathrm{sinh} \mathrm{kh}, \mathrm{qo}=\cosh \mathrm{k} \ell / \mathrm{sinh} \mathrm{kh}$ である。

$\mathrm{mz}, \mathrm{mx}$ は鉛直及び氷平方向の付加質量で, 静水中動摇実験から得られる值をすべての周期にわたって一定値 として使用するが, 浮体形状の対称性を考劣ると $\mathrm{mx}=\mathrm{mz}$ である。また办粒子加速度の平均值は浮体中心位置 $z=0$ での值を用いる。したがって本解析では波強制力を水粒子加速度と同位相の力, 即ち慣性力のみで近似 していることになる。静止無限流体中で振動する球の付加質量としては, 球体の排除する流体質量の $1 / 2$ を考 えればよいとするポテンシャル理論の値を用いると, 当然ながら(5)式と(7)式, あるいは(6)式と(8)式の和から計 算される慣性力係数は 1.5 となることが確められる。

\section{2-3 運動方程式の係数}

本解析に打いては付加慣性モーメント, 付加質量及び減衰定数は静水中動摇実験によって得られる自由動摇 曲線から求める。この方法では固有周期の運動に関する情報しか得られないため, その他の周期の運動を推定 する場合には厳密性にかけることになるが, 大略の推定は可能である。まず, 付加慣性モーメントは減衰項の影 響を無視すると次式で与えられる。

$$
\mathrm{I}^{\prime}=\left(\frac{\mathrm{T}}{2 \pi}\right)^{2} \times \mathrm{C}_{3} l-\mathrm{I}
$$

ここで, Tは固有周期であり, 付加質量 $\mathrm{mx}, \mathrm{mz}$ は近似的に $\mathrm{mx}=\mathrm{mz}=\mathrm{I}^{\prime} / \ell^{2}$ で計算される。

また線型隇衰係数は以下のよらにして求められる。本解析では(1)式に示したように浮体の運動に基づく抵抗 モーメントが浮体の運動速度及び速度の 2 乗に比例する抵抗モーメントの和から成ると仮定している。前者は 造波に基づくものであり, 後者は摩擦や造渦に基づくものであるが,これらの成分は自由動摇試験の記録から 得られる滅隇 (减衰) 曲線を用いて次のよらにして分離できる ${ }^{3)}$ 。まず，(1)，2 乗に比例する抵抗力による仕 事量を球の抗力係数として $\mathrm{C} \mathrm{D}=0.5$ を採用して計算する。次に，(2). 減隇曲線から抵抗力によってなされた 
全仕事量を計算し，(1)で計算された仕事量を差引く。(3)，(2)で計算された残りの仕事量が速度に比例する抵抗 力によってなされたものとして線型減衰俰数を求める。

\section{2-4 運動方程式の解}

(1)式は 2 階の非線型微分方程式であるため, このままでは簡単に解を求めることができない。本解析では非 線型項を準線型化して解を求める方法と数值計算によって解を求める方法によって解を求めることとする。ま ず, 準線型化による方法の計算手順は以下の通りである。いま, 水粒子と浮体運動の相対速度を $\mathbf{u}-\dot{\theta} \ell=$ $\mathrm{U} 0 \sin (\sigma \mathrm{t}+\delta)$ とし, 非線型項をフーリエ級数に展開して第 1 項をとると次式のよらになる。

$$
(\mathrm{u}-\dot{\theta} \ell)|\mathrm{u}-\dot{\theta} \ell|=\frac{8}{3 \pi} \quad \mathrm{U}^{2} 0 \sin (\sigma \mathrm{t}+\delta)
$$

ここで, 回転運動の振幅を $\theta 0$,表面波形に対する位相差をととして, $\theta=\theta \cdot 0 \cos (\sigma \mathrm{t}-\varepsilon)$ とすれば, 無次元 運動振幅 $\theta 0 \ell / \zeta 0$ をと括いて

$$
\mathrm{U} 0=\sigma \zeta 0\left(\mathrm{~A}^{2}+2 \mathrm{Aq} 0 \sin \varepsilon+\mathrm{q} 0^{2}\right)^{1 / 2}, \quad \tan \delta=-(\mathrm{q} 0+\mathrm{A} \sin \varepsilon) /(\mathrm{Acos} \varepsilon)
$$

となる。球形浮体の運動振幅と位相差 $(\theta 0, \varepsilon)$ を求め運動を確定するには，(1)式に(10), (11)式を代入して解け ばよいが,これを実際に解くことは困難なので次のような方法によって解を求める ${ }^{2)}$ 。まず，(10)式を变形して (1)式に代入すると次式が得られる。

$$
\left(\mathrm{I}+\mathrm{I}^{\prime}\right) \ddot{\theta}+\mathrm{C}_{1} \ell^{2 \dot{\theta}}+\mathrm{C}_{3} \ell \theta=\mathrm{Fx} \ell+\frac{8}{3 \pi} \mathrm{C}_{2} \ell \mathrm{U} 0(\mathrm{u}-\dot{\theta} \ell)
$$

そこでU0を仮定して(12)式を解き，兄られた $(\theta 0, \varepsilon)$ の值を用いて(11)式から再 びU0を計算する。この計算をUの値が収束するまで繰返す。実際の計算ではU0

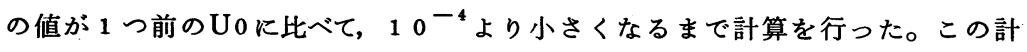
算法では絽返し計算が含をれるため数值計算法に比べて有利な点は見当らない が, 線型减衰定数が小さく, 共振点付近の運動のように浮体の運動速度が水粒 子速度に比べて非常に大きい場合, 即ち $\mathrm{u}-\dot{\theta} \ell=-\dot{\theta} \ell$ 成立するよらな条件 の下では(1)式は次式のように簡略化されるため, 非線型項を準線型化すること によって面倒な計算を行らことなく解は解析的に求まることになる。

$$
\left(\mathrm{I}+\mathrm{I}^{\prime}\right) \ddot{\theta}+\mathrm{C}_{2} \ell^{3} \dot{\theta}_{1} \dot{\theta}_{1}+\mathrm{C}_{3} \ell \theta=\mathrm{Fx} \ell
$$

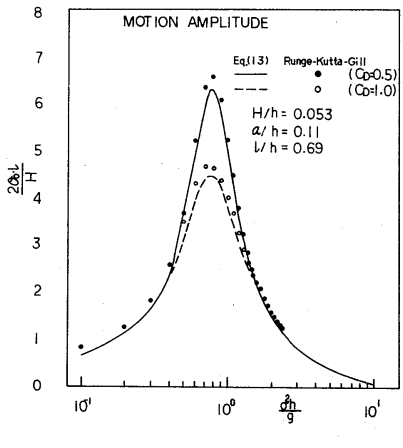

図-2 解析解と数值解 の比較

一方, 非線型微分方程式を数值計算によって解く方法には種々のものがあるが，ここではルンダ・クッタ・ジ ル法によって解を求める。例えば，(13)式は次式のように1階の連立方程式に置き換えられる。

$$
\begin{aligned}
& \dot{\mathrm{y}}_{1}=\mathrm{y}_{2} \\
& \left.\dot{\mathrm{y}}_{2}=\frac{1}{\left(\mathrm{I}+\mathrm{I}^{\prime}\right.}\right)\left\{-\mathrm{C}_{2} \ell^{8} \mathrm{y}_{2}\left|\mathrm{y}_{2}\right|-\mathrm{C}_{3} \ell \mathrm{y}_{1}+\mathrm{Fx} \ell\right\}
\end{aligned}
$$

ここで $\mathrm{y}_{1}=\theta, \mathrm{y}_{2}=\dot{\theta}$ であるしたがって初期条件を適当に設定して数值計算を行えば, 運動振幅の時間歴は 逐次計算できる。罒ー 2 には線型化法(13)式と数值計算法(14)式による計算結果の比較を示す。数値計算法におい ては初期条件は $\mathrm{t}=0$ で $\mathrm{y}_{1}=\mathrm{y}_{2}=0$ とした。ピーク付近で多少の差異はあるが, 両者はほぼ一致することが わかる。

\section{3. 不規則波中の応答解析}

不規則波中の非線型運動の解析法は既にいくつか提案されているが，ここでは合田ら ${ }^{4)}$ と同様に規則波中の 応答解析に用いた数值計算法を適用する。この方法では所定のスペクトル形状をるつ入射波のスペクトルから 波強制力をシミュレートした後, 規則波中の応答解析と同様にルンゲ・クッタ・ジル法によって運動の時間歴 
を逐次計算するものである。不規則波中の応答解析では後に述べる規則波中の応答解析結果から, 共振時の浮 体の運動速度は水粒子速度に比べて大分大きいこと, また線型減衰係数も小さいことが確めらえたため, 基本 式として(14)式を使用した。

入射波のスペクトルが与只られた場合に表面波形や水粒子速度, 加速度をシミュレートする方法はいくつ かあるが，本解析では線型重ね合せ法を用いる。いま，表面波を互いに位相関係のない成分波の線型重ね合せ として定義すれば，時刻 $\mathrm{t}$ の表面波形は次式で表現できる。

$$
\eta(\mathrm{t})={ }_{\mathrm{h}=1}^{\stackrel{\infty}{\Sigma}} \text { An } \cos (2 \pi f \mathrm{nt}+\varepsilon \mathrm{n})
$$

ここで, An, $f \mathrm{n}, \varepsilon \mathrm{n}$ はそれぞれn番目の成分波の振幅, 周波数及び $(0 \sim 2 \pi)$ の間で一様な確立で分布する位 相である。このとき, 水平方向の水粒子加速度は次式で与えられる。

$$
\mathrm{u}(z, \mathrm{t})=\underset{\mathrm{n}=1}{\infty_{\infty}} \operatorname{An}(2 \pi f \mathrm{n})^{2} \frac{\cosh \mathrm{kn}(\ell+z)}{\sinh \mathrm{knh}} \sin (2 \pi f \mathrm{nt}+\mathrm{en}) \text { (16) }
$$

表 - 1 模型諸元と静水中動摇実験結果

ここで, $(2 \pi f \mathrm{n})^{2}=\mathrm{kn} \mathrm{g} \tanh \mathrm{knh}$ である。

したがって，不規則波中においても球体に作用する水平方向の波強 制力は規則波中と同様に，水粒子加速度に比例する慣性力のみで表

\begin{tabular}{|c|c|c|c|}
\hline & \multicolumn{2}{|c|}{ MODEL } & \multirow{2}{*}{$\begin{array}{l}\text { Submerged } \\
\text { Buoy Wave } \\
\text { Meter }\end{array}$} \\
\hline & I & II & \\
\hline WEIGHT & 1930 & 434 & $\left.\right|_{\text {ton }} ^{\text {nearly }}$ \\
\hline NET BUOYANCY (g) & 2260 & 384 & ${ }^{\text {nearly }}$ ton \\
\hline MOORING DEPTH $(\mathrm{cm})$ & 66 & 58 & $10 \mathrm{~m}$ \\
\hline NATURAL PERIOD(sec) & 2.10 & 255 & $10 \sim 12 \mathrm{sec}$ \\
\hline DAMPING CONSTANT & 0.0478 & 0.0445 & \\
\hline
\end{tabular}
現できるから，次式のようになる。

$$
\mathrm{Fx}(\mathrm{o}, \mathrm{t})=\frac{4}{3} \rho \pi \mathrm{a}^{3} \mathrm{CM}_{\mathrm{n}} \underset{\mathrm{N}}{\stackrel{\sim}{\Sigma}} \operatorname{An}(2 \pi f \mathrm{n})^{2} \frac{\cosh \mathrm{kn} \ell}{\mathrm{sinh} \mathrm{knh}} \sin (2 \pi f \mathrm{nt}+\varepsilon \mathrm{n})
$$

ここで C.M は慣性力俰数であり, 完全な球形浮体の場合 には $2-2$ で述べたように本解析においても $\mathrm{C}_{M}=1.5$ である。また，成分波の振幅 An は表面波スペクトルの エネルギー密度から計算できる。したがって, 波強制力が (17)から計算されると，(14)式から不規則波中の運動は逐次 計算できることになる。係留力に関しても鉛直方向の波

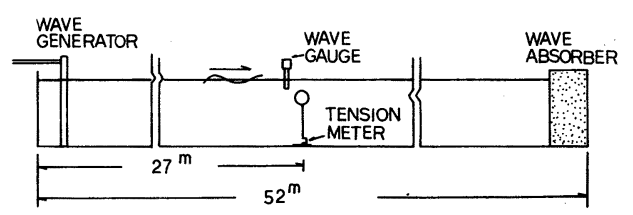

図-3 実験装置 強制力と運動から同様に計算できる。

\section{4. 模型実験及び現地実験}

規則波中の応答特性を調べ計算結果と比較するために 2 種の模型を用いた模型 実験を実施した。実験に使用した模型の諸元は表ー1亿示す通りである。(I)型は 径 $20 \mathrm{~cm}$ のほぼ完全な球形であるが，(们型は不規則波中の応答解析結果の検証に 使用する海中ブイ式波浪計 ${ }^{5)}$ の1/15 縮尺の模型で径は約 $12 \mathrm{~cm}$ である。実験に使 用した係留索は(I)型が $3 \mathrm{~mm}$ の銅線, (II)型が模型換算されたチェーンである。実験 は主として図ー3 亿示す水槽で実施し, 水深は約 $1 m$ で一定とした。浮体の運動

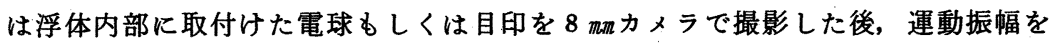
読みとることによって測定した。静水中動摇実験も同様な方法で実施した。また， 係留力はヒズミゲージを張付けた張力計によって測定した。

不規則波による球形浮体の応答データは1977年 3 月から断続的に実施してき

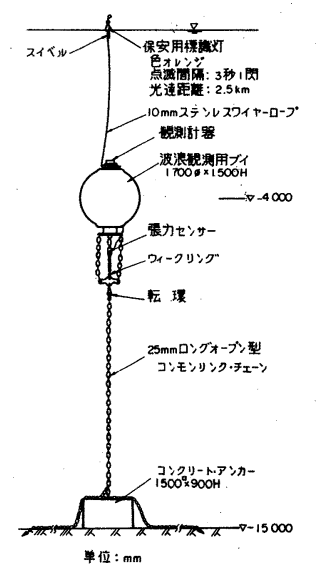

図-4 海中ブイ式波浪計 た海中ブイ式波浪計の現地実験によって得られたものを使用した。この波浪計は罒ー4に示すよらな構成とな っているが, ブイ本体は完全な球形ではない。このブイ本体の中には水圧変動測定のための水圧センサー, 動 摇角測定のための 2 成分傾斜計, それに方位計が搭載された。張力計は係留索の中間に設置された。解析に使 用したデータは 2 時間毎 15 分間に得られた観測記録である。 
5. 計算結果と実験結果の比較 規則波中の結果 - 表 1 亿示 した静水中動摇実験結果からわ かるように $2-3$ の方法で求め られた(I), (II)型の線型減衰定数 はかなり小さいことから, 本解 析で行ったような型式の球形浮 体では抵抗モーメントは大部分 粘性抵抗力に起因することがわ かる。このことは図ー5, 6 に 示す(I), (II)型の運動に関する計

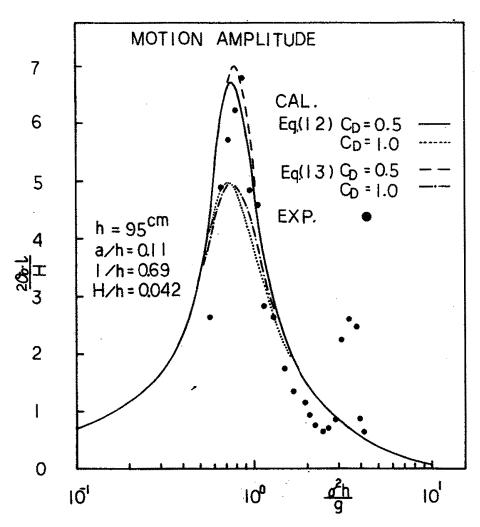

図-5計算値と実験值の比較（I型）

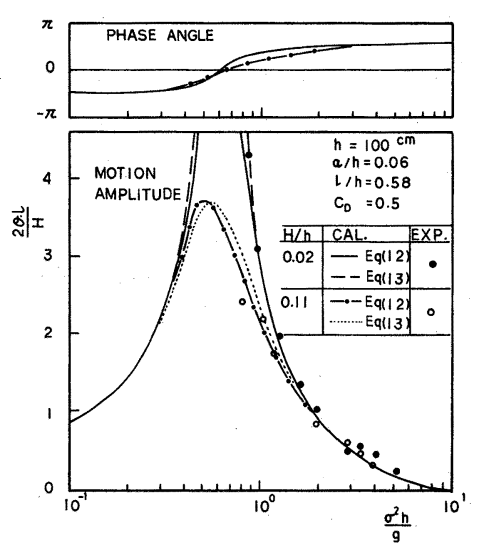

目- 6 計算値と夷験値の比較 (II型) かである。なお, 図一5,6では水平変位を波高 $\mathrm{H} て ゙$ 除した無次元值 で表現している。図ー 5 は(I)型の場合であるが， $C_{D}=0.5$ とすれば ここで示した解析法によって共振点付近の運動までうまく推定でき ることがわかる。また，式(1)と(13)の違いもそれほど大きなるのでな いことも確められる。図ー 5 においては固有周期の $1 / 2$ 周期のところ でも明瞭なピークが認められるが，このときの運動は単純な振り子 型の単振動ではなく，2 度摇れを生じるような運動であった。この 原因は明らかでなく，垷在検討中である。図一6は(II)型の場合であ る。(11)型においては形状の関係から，(9) 式から計算される付加質 量が球形の場合に比べて約 1.4 倍と大きくなっているが, 没高の違 いによる運動振幅の変化特性は計算值と実験値ではよく一致してい

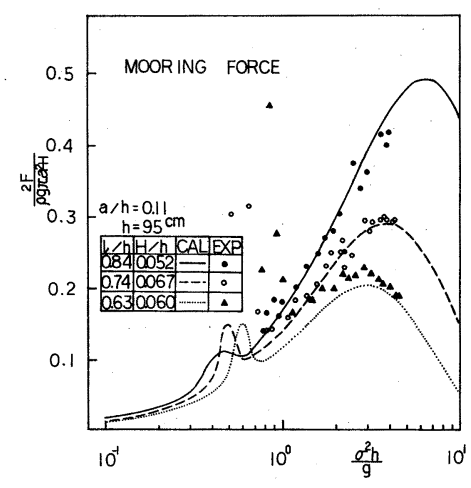

図- 7 計算值と実験値の比較（I型） る（四型では, 固有周期の $1 / 2$ 周期のところでは特にピークは認められ ない。位相差の計算結果も示しているが共振点付近を除けば土 $/ 2$ に近くなることがわかる。図ー 7 に示した 係留力に関しても共振点付近を除き計算值と実験値はよく一致している。このことは共振点付近を除けば慣性 力が支配的であることを示している。共振点付近では固有周期が短い場合ほどその差が大きくなっているが, 振 動流中の実験結果 ${ }^{6)}$ から判断しても，CD，CMの値はそれほど大きな値になるとは考えにくく，また(2) 式に おいて, 左辺の項に付加質量まで加えた解析を行っても図ー7の結果と大きな差は認められないことから, 実 験方法す含めて今後さらに検討する必要がある。

不規則波中の結果 一 得られた観測記録の中で, 波高が最も大きいケース(図ー8,9)と風波ととすに固有周 期に近い波が来襲していたケース（図一 10，11）について， CD は 0.5，CM は運動の場合(9)式から得られ た值（１.906）を用いて計算した結果と実測值を比較した結果を以下に示す。この波浪計では表面波を水圧セ ンサーで測定する方式であるため，水圧スペクトルを表面波スペクトルへ換算した後，4. で述べた計算を実 施した。水王から表面波への換算には微小振幅理論を使用し, 換算係数 $\mathrm{n} は 1$ とした。また水圧記録の高周波 数側に含まれるノイズの影響を除くために, 表面波スペクトルの高周波側を $f^{-4}$ あいはfー5 に比例する形 で近似した。図ー8，10からわかるように線型重ね合せ法によってシミュレートされた表面波のスペクトル は設定スペクトルとよく一致している。この計算においてはスペクトルの分割個数は 55 個とした。4. で述べ た数値計算法では波が一方向から進入してくる場合を対象としているため, 実際の海の波のように方向分散性 あつ波を対象とする場合には, この仮定が成立しているかを確めておく必要があるが，ここでは単純に計算結 果と実測值を比較し, エネルギー密度のオーダ的な比較を行らこととする。参考までに図一 12 に浮体の運動 方向の頻度分布を示すが, これは傾斜計と方位計から計算されたものである。図ー9，10から明らかなよう 
に運動の計算値と実測值のスペクト ルは形状的にはよく一致しているが 単 1 方向の来襲波と考えられる図一 9 の場合においても計算値は実測値 に比べて少し小さい。しかし固有周 期 ( $f=0.1 \mathrm{~Hz}$ 程度) 付近の運動に ついてはょく一致している。0.2 Hz 以上の高周波数側で一致の程度がよ くない原因は, 計算方法にも多少の 問題はあろらが，七ンサーの測定精 度も影響していると考えられる。特 に傾斜計は振り子型のものを使用し たために測定精度はそれはど高いる のではない。係留力については, 図 - 11 の共振点付近を除いて C $\mathrm{M}=$ 1.5 とした計算値でよく一致してい る。これは鉛直方向で考えるとブイ はほほ球形とみなせるためと考えら れる。また図一 9 の水圧と係留力の 位相差をみるとほとんどの周波数で
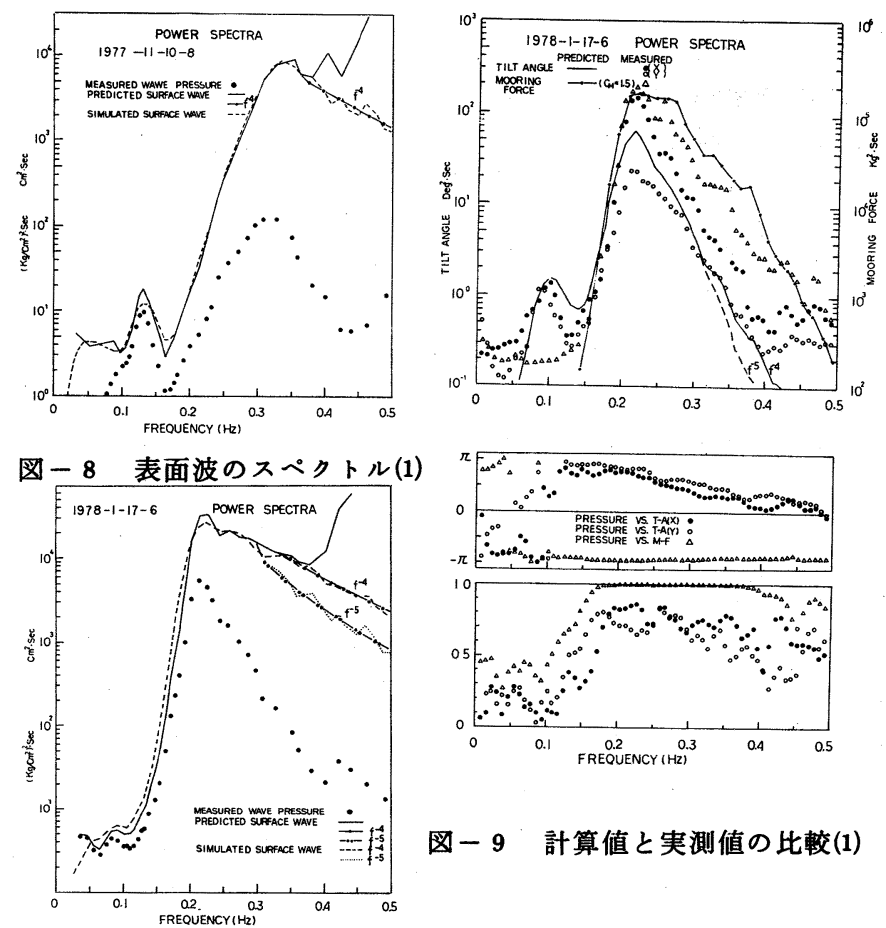

図-9計算値と実測値の比較(1)

一 ことが明らかである。共振点付近では規則波中 と同様に実測値が大さなる傾向が認めら れる。

\section{6. 結 言}

これまで述べたように本論文で示した解析方 法によって海中に 1 点緊張係留された球形浮体 の規則波及び不規則波中の運動と係留力は大略 推定できるが, 共振時の挙動に関連していくつ図-12 運動方向

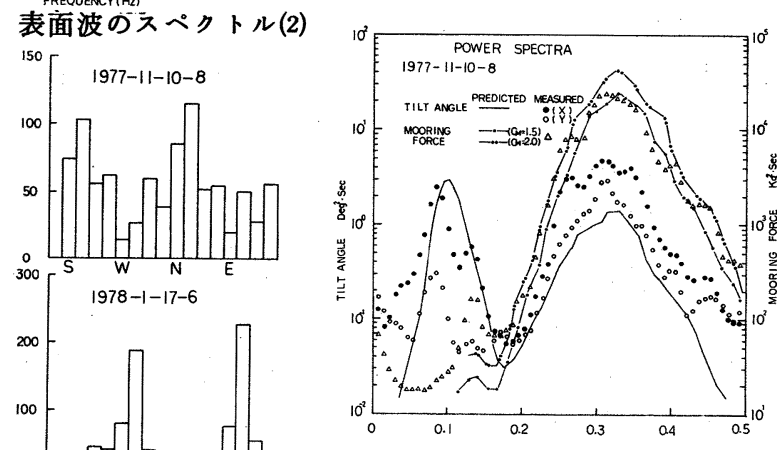

図-11 計算値と実涺値の比較(2) かの点で説明できない事柄が残されている。これらの点については検討中であり，別途報告する予定である。 参考文献

1）たとえば, Harleman, Donald R.F. and Shapiro, William C.: The Dynamics of a

Submerged Moored Sphere on Oscillatory Waves, Proc. of $7 \mathrm{th}$ Corf on Coatal Eng., $1960, \mathrm{pp} \cdot 746 \sim 765$

2) 田才福造：浮遊構造物に働らく流体力とその運動について, 九州大学応用力学研究所, 1971

3）大串雅信：理論船舶工学 (下), 海文堂

4）合田良実 ·鈴木康正 ·蜂須賀和吉：直立式円筒浮体の波浪中の動摇振幅に関する研究, 港湾技術研究所報 告, 第 17 巻第 4 号, $1978, \mathrm{p} \mathrm{p} .89 \sim 120$

5）橋本宏・山口修：海中ブイ式波泿計による波浪観測, 第 25 回海岸工学講演会論文集, 1978, p p.60 64

6) Sarpkaya, T. : Forces on Cylinders and Spheres in a S inusoidally Qscillat ing

Fluid, Jour. of Applied Mech., 1975, pp.32 37 